\title{
SISTEM PENDUKUNG KEPUTUSAN PEMILIHAN SISWA BERPRESTASI DI SMP NEGERI 1 POLOKARTO SUKOHARJO MENGGUNAKAN METODE WEIGHTED PRODUCT (WP)
}

\author{
Aqoid Mustofa Ardhi ${ }^{1)}$, Dwi Remawati ${ }^{2)}$, Sri Hariyati Fitriasih ${ }^{3)}$ \\ ${ }^{1)}$ Program Studi Teknik Informatika, STMIK Sinar Nusantara Surakarta \\ ${ }^{2)}$ Program Studi Teknik Informatika, STMIK Sinar Nusantara Surakarta \\ ${ }^{3)}$ Program Studi Sistem Informasi, STMIK Sinar Nusantara Surakarta \\ 1) tovaardhi@gmail.com), ${ }^{2)}$ dwirema@ sinus.ac.id, ${ }^{3)}$ fitri@ sinus.ac.id
}

\begin{abstract}
This research is to make decision support system from student selection achievement in SMP Negeri 1 Polokarto Sukoharjo which still done manually. The method used is weighted product. System design using UML. Testing this system aims to find the level of validity of the system that applies the weight of algorithm products with MS.excel calculation with the same criteria and the same weight on each alternative for the results of calculating the distance relative to the ideal solution manual. The result of this research is making decision support system from student achievement.
\end{abstract}

Keywords: decision support system, student selection achievement, weighted product

\section{PENDAHULUAN}

Pemilihan siswa berprestasi perlu dilakukan di sebuah sekolah. Tujuannya adalah untuk menyaring siswa yang memiliki prestasi untuk dilakukan pembinaan sehingga prestasinya meningkat. Siswa berprestasi juga akan membawa nama baik untuk sekolah, disamping juga berguna untuk siswa sendiri sebagai nilai tambah ketika akan melanjutkan sekolah ke jenjang yang lebih tinggi.

SMP Negeri 1 Polokarto Sukoharjo sebagai suatu sekolah juga menerapkan pemilihan siswa berprestasi. Selama ini pemilihan dilakukan secara manual yaitu dengan melihat prestasi yang telah dicapai oleh siswa.

Perlu adanya sebuah sistem yang dapat membantu dalam proses pengambilan keputusan untuk proses pemilihan Siswa Berprestasi. Sistem yang akan dibangun ini menggunakan algoritma Weighted Product (WP). Untuk pemecahan masalahnya dan diharapkan sistem ini mampu membantu mendukung suatu pengambilan keputusan yang dilakukan secara lebih obyektif. Hasil dari proses sistem ini adalah berupa daftar peringkat berprestasi yang akan diusulkan pada proses pemilihan Siswa Berprestasi. Oleh karena dari permasalahan diatas penulis ingin mengajukan judul "Sistem Pendukung Keputusan Pemilihan Siswa Berprestasi Menggunakan Algoritma Weighted Product (WP) Pada SMP Negeri 1 Polokarto Sukoharjo".

\section{TINJAUAN PUSTAKA}

\subsection{Sistem}

Sistem adalah suatu jaringan kerja dari prosedur-prosedur yang saling berhubungan, berkumpul bersama-sama untuk melakukan suatu kegiatan atau untuk menyelesaikan suatu sasaran tertentu.'Pendekatan sistem yang menekankan pada komponen atau elemennya mendefinisikan sistem sebagai berikut : "Sistem adalah kumpulan dari elemen-elemen yang berinteraksi untuk mencapai suatu tujuan tertentu." Dari kedua pendekatan di atas, peneliti menyimpulkan bahwa sistem adalah kumpulan dari 
elemen- elemen atau sub-sub sistem yang saling berintegrasi dan saling berhubungan satu sama lain membentuk satu kesatuan utuh untuk melaksanakan suatu fungsi guna mencapai suatu tujuan tertentu. (Nugroho, Remawati, \& Widada, 2016)

\subsection{Sistem Pendukung Keputusan}

Sistem Pendukung Keputusan (SPK) dapat didefinisikan sebagai suatu program komputer yang menyediakan informasi dalam domain aplikasi yang diberikan oleh suatu model analisis keputusan dan akses ke database, dimana hal ini ditujukan untuk mendukung pembuat keputusan (decision maker) dalam mengambil keputusan secara efektif baik dalam kondisi yang kompleks dan tidak terstruktur. Sistem organisasi paling tidak mencakup sistem fisik (sistem operasional), sistem manajemen (sistem keputusan), dan sistem informasi. (Noviansyah, 2014)

\subsection{Weighted Product (WP)}

Metode Weighted Product (WP) merupakan salah satu metode penyelesaian yang ditawarkan untuk menyelesaikan masalah Multi Attribute Decision Making (MADM). Metode Weighted Product mirip dengan Metode Weighting Sum (WS), hanya saja metode Weighted Product (WP) terdapat perkalian dalam perhitungan matematikanya. Metode Weighted Product juga disebut analisis berdimensi karena struktur matematikanya menghilangkan satuan ukuran. Metode Weighted Product (WP) menggunakan perkalian untuk menghubungkan rating atribut, dimana rating setiap atribut harus dipangkatkan dulu dengan bobot atribut yang bersangkutan. Proses ini sama halnya dengan proses normalisasi. Preferensi untuk alternatif diberikan sebagai berikut :

$$
S_{i}=\prod_{j=1}^{n} x_{i j} w_{j}
$$

dengan $\mathrm{i}=1,2, \ldots, \mathrm{m}$. Dimana $\sum \mathrm{w}_{\mathrm{j}=1}, \mathrm{w}_{\mathrm{j}}$ adalah pangkat bernilai positif untuk atribut keuntungan, dan bernilai negatif untuk atribut biaya. Ditemukan urutan alternatif terbaik yang akan menjadi keputusan. (Rohmah \& Remawati, 2016)

\subsection{Web}

Web adalah bagian tertentu dari berbagai dokumen yang saling dihubungkan satu sama lain sehingga terbentuk jejaring web yang saling kait-mengait. Apabila diimplementasikan dalam sebuah jaringan komputer, dokumen yang berada dalam jaringan semacam itu dapat berdiam pada mesin-mesin berbeda membentuk sebuah jaring yang membentuk seluruh jaringan komputer. (Sari, Remawati, \& Widada, 2017)

\subsection{Unified Modeling Language (UML)}

UML adalah sebuah bahasa yang berdasarkan grafik atau gambar untuk menvisualisasikan, menspesifikasikan, membangun dan pendokumentasian dari sebuah sistem pengembangan perangkat lunak berbasis Objek. Pemetaan (mapping) Unified Modeling Language (UML) bersifat dua arah yaitu :

a. Generasi kode bahasa pemprograman tertentu dari Unified Modeling Language (UML) forward engineering. 
b. Generasi kode belum sesuai dengan kebutuhan dan harapan pengguna, pengembang dapat melakukan langkah balik bersifat iterative dari implementasi ke UML hingga didapat sistem/peranti lunak yang sesuai dengan harapan pengguna dan pengembang. (Ladjamudin, 2006)

\section{METODE PENELITIAN}

Metode penelitian yang dilakukan adalah dengan menggabungkan data primer serta data sekunder. Sedangkan metode pengumpulan data dilakukan dengan wawancara, observasi serta studi pustaka. Perancangan sistem menggunakan UML meliputi Use Case Diagram, rancangan alur kerja (Aktivity Diagram), rancangan antar class (Class Diagram), dan rancangan integrasi antar objek (sequence Diagram).

\section{HASIL DAN PEMBAHASAN}

\subsection{Analisa Sistem}

Perancangan sistem dilakukan untuk pembentukan sistem secara umum yang meliputi use case, activity diagram,sequence diagram,class diagram.

a. Use case

Pada Gambar 1 terdapat dua actor pada sistem pendukung keputusan pemilihan siswa berprestasi yaitu kurikulum dan petugas. petugas dalam hal ini adalah orang yang dapat mengelola halaman administrator seperti menginput data ke dalam database, sedangkan kurikulum adalah yang dapat melihat hasil laporan sebagai bahan pertimbangan pengambilan keputusan.

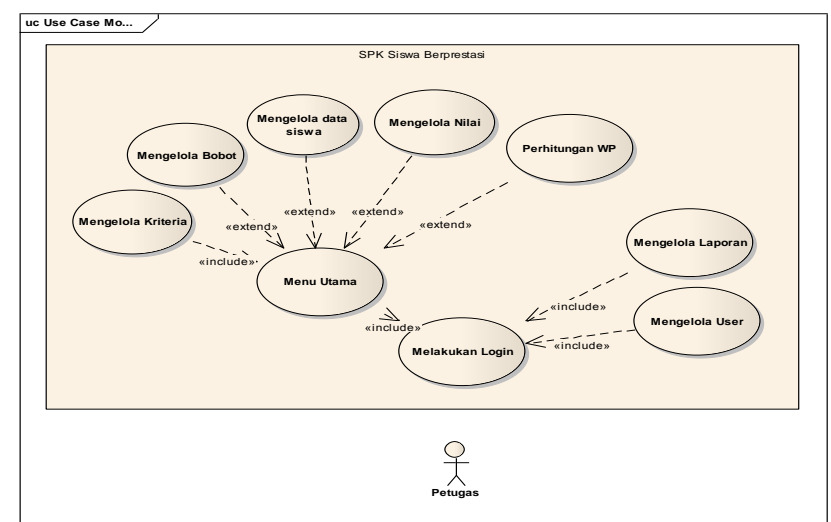

Gambar 1. Use case diagram

\section{b. Activity Diagram}

Activity diagram menggambarkan berbagai alir aktivitas dalam sistem yang sedang dirancang, bagaimana masing-masing alir berawal, decision yang mungkin terjadi, dan bagaimana mereka berakhir.

- Mengelola Kriteria

Activity diagram pada Gambar 2 berfungsi memasukkan nilai kriteria dan bobot kriteria. Cara kerjanya adalah kurikulum melakukan login kemudian memilih menu mengelola kriteria lalu memasukkan nilai kriteria dan bobot kriteria. 


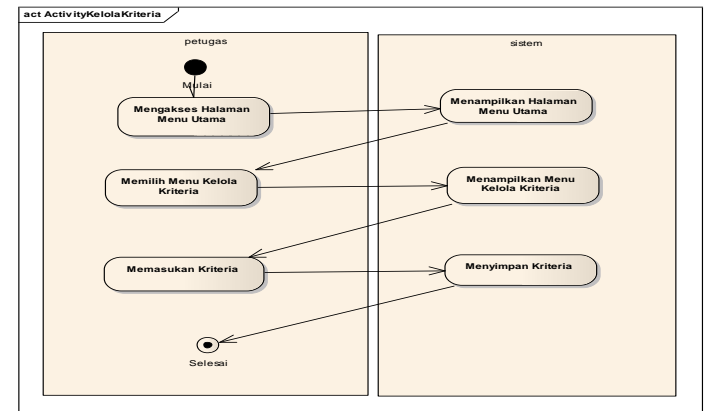

Gambar 2.Activity mengelola criteria

- Mengelola Nilai

Activity diagram pada Gambar 3 berfungsi untuk menambah, merubah, serta menghapus data nilai mata pelajaran siswa dari tiap kriteria. Cara kerjanya adalah petugas melakukan login kemudian memilih menu mengolah data siswa, petugas memasukkan data siswa.

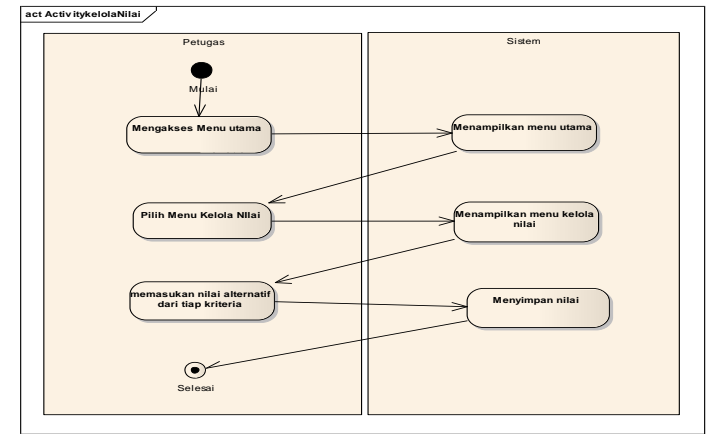

Gambar 3. Activity Mengelola Nilai

- Perhitungan WP

Activity diagram Pada Gambar 4 berfungsi untuk melakukan proses perhitungan algoritma weighted product. Cara kerjanya adalah petugas mengakses halaman utama, kemudian memilih menu halaman perangkingan dan memilih menu perhitungan WP.

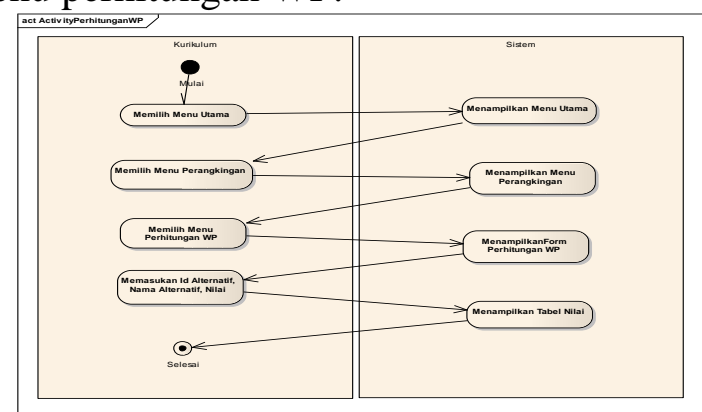

Gambar 4. Activity Perhitungan WP

c. Sequence Diagram

Sequence Diagram digunakan untuk menggambarkan skenario atau rangkaian langkah-langkah yang dilakukan sebagai sebuah respon dari suatu kejadian/even untuk menghasilkan output tertentu. 
- Mengelola Kriteria

Sequence diagram pada Gambar 5 berfungsi memasukkan nilai kriteria dan bobot kriteria dengan mencocokkan data yang ada pada tabel kriteria. Cara kerjanya adalah petugas melakukan login kemudian memilih menu kriteria lalu memasukkan nilai kriteria dan bobot kriteria.

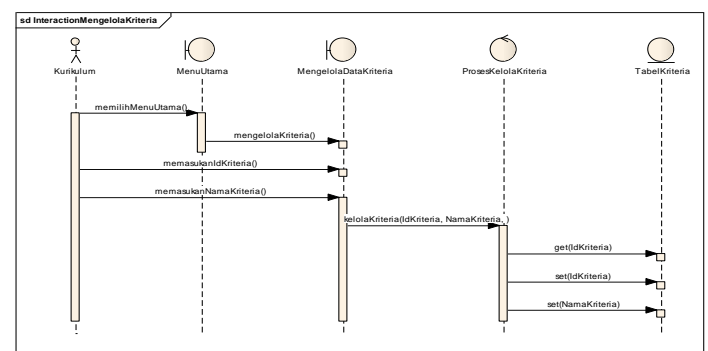

Gambar 5. Sequence mengelola kriteria

- Mengelola nilai

Sequence diagram pada Gambar 6 berfungsi memasukkan nilai siswa dari tiap kriteria dengan mencocokkan data yang ada pada tabel nilai. Cara kerjanya adalah petugas melakukan login kemudian memilih menu nilai lalu memasukkan nilai siswa pada tiap kriteria.

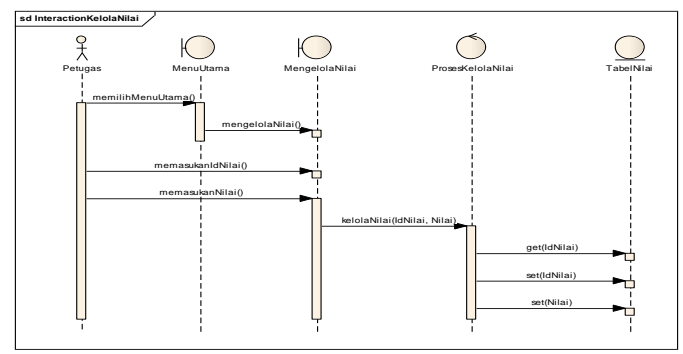

Gambar 6. Sequence kelola nilai

\section{d. Class Diagram}

Pada Gambar 7 menjelaskan tentang Class Diagram dari sistem pemilihan siswa berprestasi.

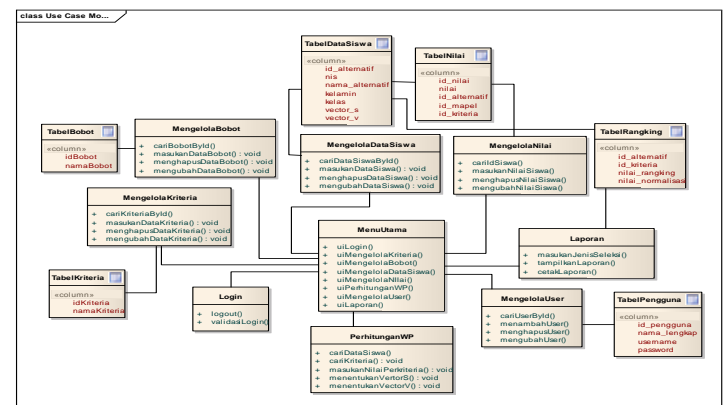

Gambar 7. Class Diagram

\subsection{Analisa Dengan Metode Weighted Product (WP)}

\section{a. Kriteria}

Dalam tahap ini adalah suatu kegiatan untuk menentukan kriteria dalam pemilihan siswa berprestasi. Dimana dalam tahap analisa membutuhkan suatu parameter kriteria. Kriteria dan Bobot ditampilkan pada Tabel 1 sebagai berikut : 
Tabel 1. Tabel kriteria dan bobot

\begin{tabular}{|l|c|}
\hline \multicolumn{1}{|c|}{ Kriteria } & Bobot \\
\hline Nilai Raport semester 1 & $\mathbf{0 , 3 7 5}$ \\
\hline Nilai Raport semester 2 & $\mathbf{0 , 3 7 5}$ \\
\hline Sikap & $\mathbf{0 , 1 2 5}$ \\
\hline Nilai extra kurilkuler & $\mathbf{0 , 1 2 5}$ \\
\hline
\end{tabular}

\section{b. Perhitungan Algoritma}

1. Hasil nilai rata - rata untuk mencari nilai alternatif disetiap kriteria dimana perhitungannya dijumlah persubkriteria dan ditambahkan setelah itu dibagi jumlah perkriteria dan hasilnya ditunjukkan di Tabel 2:

Tabel 2.nilai rata rata setiap kriteria alternatif

\begin{tabular}{|l|c|r|c|c|}
\hline \multirow{2}{*}{ Nama Siswa } & \multicolumn{4}{|c|}{ Kriteria } \\
\cline { 2 - 5 } & C1 & \multicolumn{1}{|c|}{ C2 } & \multicolumn{1}{c|}{ C3 } & C4 \\
\hline Bagus Pandu P & 74,58 & 81,08 & 80,92 & 81,25 \\
\hline Ahmad Mustofa & 85,17 & 84,17 & 85,33 & 86,17 \\
\hline Andre Nugroho & 87,92 & 86,5 & 86,75 & 86,83 \\
\hline Anis Taryanti & 86,33 & 84,83 & 86,25 & 86,67 \\
\hline Anny Dya I & 80,00 & 81,17 & 81,67 & 82,83 \\
\hline
\end{tabular}

2. Setelah menghitung jumlah setiap kriteria seperti Tabel 2, selanjutnya memberikan nilai bobot pada setiap kriteria dimana untuk menghitung bobot kriteria, digunakan perbandingan berpasangan yaitu membandingkan antara satu kriteria dengan kriteria yang lain. Hasil nilai bobot pada setiap kriteria terdapat pada Tabel 1.

3. Setelah mendapatkan nilai bobot diatas selanjutnya menghitung nilai vektor $\mathrm{S}$ dari Tabel 2 yang berisi data siswa yang sudah dinilai sebagai berikut:

$$
\begin{aligned}
\mathrm{S}_{1}= & \text { Bagus Pandu Perdana }=\left(74,58^{0,38}\right) \times\left(81,08^{, 0,38}\right) \times\left(80,92^{0,12}\right) \times \\
& \left(81,25^{0,12}\right) \\
= & 78,54911 \\
\mathrm{~S}_{2}= & \text { Ahmad Mustofa }=\left(85,17^{, 38}\right) \times\left(84,17^{, 0,38}\right) \times\left(83,55^{0,12}\right) \times\left(86,17^{0,12}\right) \\
= & 84,92405 \\
\mathrm{~S}_{3}= & \text { Andre Nugroho }=\left(87,92^{0,38}\right) \times\left(86,5^{0,38}\right) \times\left(86,75^{0,12}\right) \times\left(86,83^{0,12}\right) \\
= & 87,10597 \\
\mathrm{~S}_{4}= & \text { Anis Taryanti }=\left(86,33^{0,38}\right) \times\left(84,83^{, 0,38}\right) \times\left(86,25^{0,12}\right) \times\left(86,67^{0,12}\right) \\
= & 85,78996 \\
\mathrm{~S}_{5}= & \text { Anny Dya Irawati }=\left(80,00^{0,38}\right) \times\left(81,17^{0,38}\right) \times\left(81,67^{0,12}\right) \times\left(82,83^{0,12}\right) \\
= & 80,97813
\end{aligned}
$$

Dibawah ini Tabel 3 perhitungan untuk mencari nilai vektor S yang sudah dijumlahkan : 
Tabel 3. Tabel Nilai Vektor S

\begin{tabular}{|l|c|}
\hline \multicolumn{1}{|c|}{ Nama Alternatif } & Nilai S \\
\hline Bagus Pandu Perdana & 78,54911 \\
\hline Ahmad Mustofa & 84,92405 \\
\hline Andre Nugroho & 87,10597 \\
\hline Anis Taryanti & 85,78996 \\
\hline Anny Dya Irawati & 80,97813 \\
\hline
\end{tabular}

Setelah memperoleh nilai vektor S selanjutnya mencari nilai vektor V yang digunakan untuk perangkingan dengan dihitung sebagai berikut :

$$
\begin{aligned}
& V_{1}=\text { Bagus Pandu Perdana }=\frac{S_{1}}{S_{1}+S_{2}+S_{3}+S_{4}+S_{5}} \\
& =\frac{78,54911}{78,54911+84,92405+87,10597+85,78996+80,97813} \\
& \quad=0,1882105 \\
& V_{2}=\text { Ahmad Mustofa }=\frac{S_{2}}{S_{1}+S_{2}+S_{3}+S_{4}+S_{5}} \\
& =\frac{84,92405}{78,54911+84,92405+87,10597+85,78996+80,97813} \\
& \quad=0,2034854 \\
& V_{3}=\text { Andre Nugroho }=\frac{S_{3}}{S_{1}+S_{2}+S_{3}+S_{4}+S_{5}} \\
& =\frac{87,10597}{78,54911+84,92405+87,10597+85,78996+80,97813} \\
& =0,2087134 \\
& V_{4}=\text { Anis Taryanti }=\frac{S_{4}}{S_{1}+S_{2}+S_{3}+S_{4}+S_{5}} \\
& =
\end{aligned}
$$

Proses selanjutnya adalah menjumlahkan tiap kriteria dari masingmasing calon siswa teladan dibuat rangking berdasarkan jumlah dari tiap kriteria yang telah dijumlahkan seperti pada Tabel 4 berikut :

Tabel 4. Hasil perangkingan mencari nilai V

\begin{tabular}{|l|l|c|}
\hline Nama Alternative & Nilai V & Rangking \\
\hline V1. Bagus Pandu P & 0,1882105 & 5 \\
\hline V2. Ahmad Mustofa & 0,2034854 & 3 \\
\hline V3. Andre Nugroho & 0,2087134 & 1 \\
\hline V4. Anis Taryanti & 0,2055602 & 2 \\
\hline V5. Anny Dya Irawati & 0,1940306 & 4 \\
\hline
\end{tabular}


Jadi proses akhir dari metode WP dari tabel diatas dapat memilih calon siswa berprestasi yang terpilih menjadi alternatif trainer terbaik adalah Andre Nugroho.

\subsection{Hasil Tampilan Program}

a. Data Kriteria

Pada Gambar 8 untuk memasukkan data kriteria yang dipersyaratkan untuk SPK pemilihan siswa berprestasi

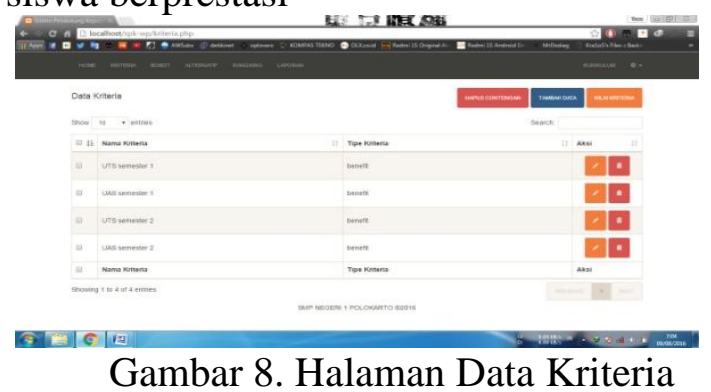

b. Data Alternatif

Gambar 8. Halaman Data Kriteria

Gambar 9 menampilkan halaman alternatif data siswa yang telah di inputkan oleh petugas.

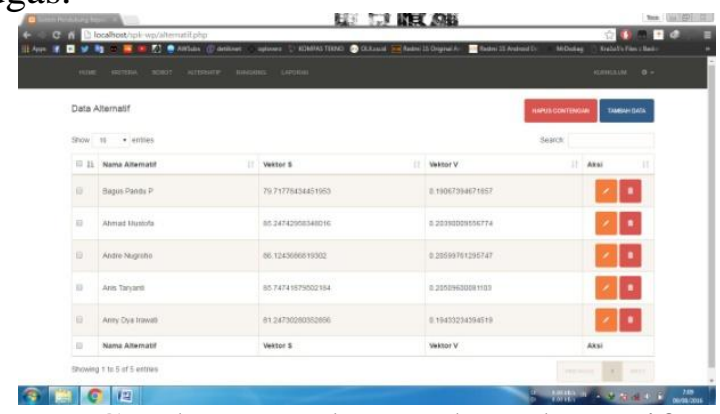

Gambar 9. Halaman data alternatif

c. Perangkingan

Gambar 10 merupakan halaman perangkingan berisi data alternatif beserta nilai dari setiap kriteria .

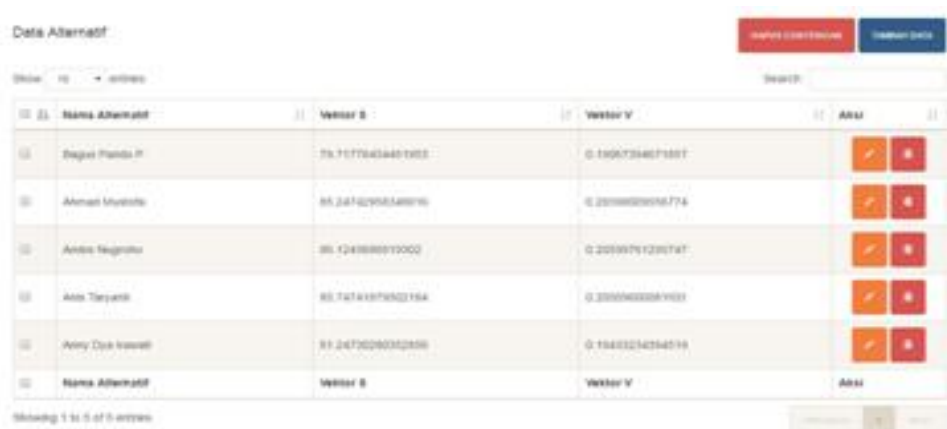

Gambar 10. Halaman perangkingan

d. Laporan

Gambar 11 merupakan halaman laporan berisi hasil perhitungan SPK pemilihan siswa berprestasi yang dapat didownload maupun dicetak yang nantinya dijadikan acuan pemilihan siswa berprestasi. 


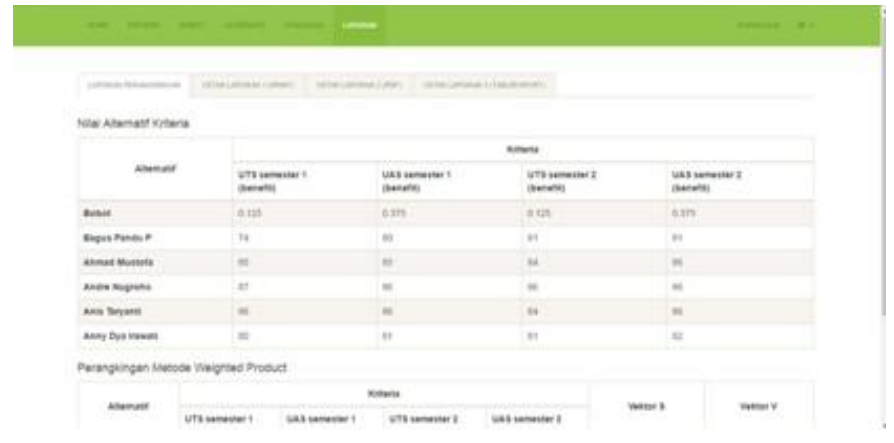

Gambar 11. Halaman laporan

\subsection{Pengujian}

Pada pengujian sistem ini bertujuan mencari tingkat validitas sistem yang menerapkan algoritma weighting product dengan perhitungan dari MS.excel dengan kriteria-kriteria yang sama dan pemberian bobot sama pada masing-masing alternative adapun hasil perhitungan kedekatan relatif terhadap solusi ideal manual dapat dilihat pada Tabel 5.

Tabel 5. Hasil perangkingan mencari nilai $\mathrm{V}$

\begin{tabular}{|l|l|l|}
\hline $\begin{array}{l}\text { Nama } \\
\text { Alternatif }\end{array}$ & Nilai S & Nilai V \\
\hline $\begin{array}{l}\text { Bagus Pandu } \\
\text { P }\end{array}$ & 78,54911 & 0,1882105 \\
\hline $\begin{array}{l}\text { Ahmad } \\
\text { Mustofa }\end{array}$ & 84,92405 & 0,2034854 \\
\hline $\begin{array}{l}\text { Andre } \\
\text { Nugroho }\end{array}$ & 87,10597 & 0,2087134 \\
\hline Anis Taryanti & 85,78996 & 0,2055602 \\
\hline $\begin{array}{l}\text { Anny Dya } \\
\text { Irawati }\end{array}$ & 80,97813 & 0,1940306 \\
\hline
\end{tabular}

Hasil perhitungan kedekatan relatif terhadap solusi ideal pada sistem dapat dilihat pada Gambar 12.

\begin{tabular}{|l|l|l|l|}
\hline$\square$ & Nama Alternatif & Vektor S & Vektor V \\
\hline$\square$ & Bagus Pandu P & 79.71778434451953 & 0.19067394671857 \\
\hline$\square$ & Ahmad Mustofa & 85.24742958348016 & 0.20390009556774 \\
\hline & Andre Nugroho & 86.1243686819302 & 0.20599761295747 \\
\hline$\square$ & Anis Taryanti & 85.74741879502184 & 0.20509600081103 \\
\hline$\square$ & Anny Dya Irawati & 81.24730280352856 & 0.19433234394519 \\
\hline
\end{tabular}

Gambar 12.hasil pencarian nilai V dengan sistem 


\section{PENUTUP}

\subsection{Kesimpulan}

Kesimpulan yang dapat diambil adalah sebagai berikut :

1. Terciptanya sebuah Sistem Pendukung Keputusan Pemilihan Siswa Berprestasi di SMP Negeri 1 Polokarto Sukoharjo dengan menggunakan metode Weighted Product (WP).

2. Menghasilkan aplikasi yang bisa digunakan oleh semua bagian untuk perbaikan kinerja, mengolah penilaian dengan sistem WP dan menyimpan laporan Hasil penilaian sehingga akan menghasilkan suatu informasi yang dibutuhkan.

\subsection{Saran}

Berikut saran untuk pengembangan sistem selanjutnya:

1. Aplikasi ini hanya sebagai pendukung keputusan pimpinan atau yayasan bukan untuk mengubah atau mengganti keputusan pimpinan atau yayasan.

2. Berharap kedepannya perlu dibuat pengembangan, juga bisa menggunakan metode yang lain yaitu : metode TOPSIS ,SAW atau AHP sebagai bahan pembanding dan agar alternatif yang dihasilkan dapat lebih akurat.

\section{DAFTAR PUSTAKA}

Ladjamudin, A.-B. B. (2006). Rekayasa Perangkat Lunak. Jakarta: Elekmedia Komputindo .

Noviansyah, D. (2014). Konsep Data Mining vs Sistem Pendukung Keputusan. Yogyakarta: Deepublish.

Nugroho, B., Remawati, D., \& Widada, B. (2016). Implementasi Metode WP (Weihhted Product) Untuk Mendukung Keputusan Penjurusan Siswa Di SMA Negeri 1 Grobogan. Jurnal Teknologi Informasi dan Komunikasi (TIKomSiN), Vol 4, No. 2 , 54 - 61.

Rohmah, N., \& Remawati, D. (2016). Penerapan Metode Weighted Product (WP) Untuk Penerimaan Pegawai Baru Di PT. Tiga Serangkai Pustaka Mandiri Surakarta. Jurnal Ilmiah SINUS, Vol 14, No. 2 , 41 - 58.

Sari, S., Remawati, D., \& Widada, B. (2017). Sistem Informasi Monitoring Dan Evaluasi Belajar Siswa Berbasis WEB Dan SMS Gateway Di SDIT Nurul Istiqlal Klaten. Jurnal Ilmiah SINUS, Vol 15, No 1, 59 - 70. 